\title{
Pengaruh Stres Kronis Terhadap Apoptosis Sel Granulosa Folikel Antral Rattus Norvegicus
}

\author{
Andina Bella Rahadi Putri ${ }^{1}$, Margarita M. Maramis ${ }^{2}$, Jimmy Yanuar Annas ${ }^{3}$ \\ ${ }^{1}$ Mahasiswa Ilmu Kesehatan Reproduksi Jenjang Magister, Fakultas Kedokteran, \\ Universitas Airlangga Surabaya \\ ${ }^{2}$ Departemen Ilmu Kesehatan Jiwa, Fakultas Kedokteran, Universitas Airlangga, RSUD \\ Dr. Soetomo \\ ${ }^{3}$ Departemen Obstetri dan Ginekologi, Fakultas Kedokteran, Universitas Airlangga, \\ RSUD Dr. Soetomo \\ e-mail : bellandina@gmail.com
}

\begin{abstract}
ABSTRAK
Stres kronis dapat menginduksi aktivasi dari hipotalamus-hipofisis-adrenal (HPA) axis secara terus menerus sehingga dapat menyebabkan gangguan pada proses folikulogenesis. Tingginya kadar glukokortikoid akibat stres kronis dapat menginduksi apoptosis sehingga mengganggu homeostasis didalam folikel. Adanya apoptosis sel granulosa dapat menyebabkan gangguan pada folikulogenesis dengan menurunkan komunikasi antara sel granulosa - oosit yang kemudian mempengaruhi suplai nutrisi dan faktor pematangan oosit sehingga mempengaruhi kualitas oosit. Membuktikan jumlah apoptosis sel granulosa lebih tinggi pada kelompok stres kronis. Subyek penelitian menggunakan Rattus norvegicus betina yang dibagi menjadi 2 kelompok, kontrol dan perlakuan. Kelompok perlakuan diberikan paparan stres kronis melalui metode Chronic Unpredictable Mild Stress (CUMS) selama 21 hari. Pengamatan apoptosis sel granulosa menggunakan teknik imunohistokimia dan dideteksi dengan Terminal Deoxynucleotidyl Transferase dUTP Nick End Labeling (TUNEL). Apoptosis sel granulosa antar kelompok dianalisis menggunakan uji independent t-test. Pada pengamatan apoptosis sel granulosa folikel antral menyatakan adanya perbedaan bermakna $(p=0.000)$ apoptosis sel granulosa folikel antral antara kelompok kontrol dan perlakuan. Mean $\pm S D$ kelompok kontrol $1.12 \pm 0.48$, kelompok perlakuan $3.65 \pm 1.37$. Dapat disimpulkan stres kronis memengaruhi peningkatan apoptosis sel granulosa folikel antral pada Rattus norvegicus.
\end{abstract}

Kata kunci: stres kronis, CUMS, apoptosis sel granulosa, folikel antral 


\begin{abstract}
Chronic stress could induce activation of the hypothalamic-pituitary-adrenal (HPA) axis continuously, it caused disruption in the folliculogenesis process. High levels of glucocorticoids due to chronic stress could induce apoptosis thus disrupting homeostasis in the follicles. The presence of granulosa cell apoptosis caused disruption in folliculogenesis by reducing communication between granulosa-oocyte cells which then affect nutrient supply and oocyte maturation factors that affected oocyte quality. This research aimed to prove the amount of granulosa cell apoptosis was higher in chronic stress groups. Research subjects were female Rattus norvegicus which was divided into 2 groups, control and treatment. The treatment group was given chronic stress exposure through the Chronic Unpredictable Mild Stress (CUMS) method for 21 days. Observation of granulosa cell apoptosis used immunohistochemical techniques and detected with Terminal Deoxynucleotidyl Transferase dUTP Nick End Labeling (TUNEL). Granulosa cell apoptosis between groups was analyzed using independent t-test. In the observation of apoptosis of antral follicle's granulosa cells, there were significant differences ( $p=0.000)$ of apoptosis of granulosa cells in antral follicles between the control and treatment groups. Control group's mean $\pm S D$ were $1.12 \pm 0.48$ and in the treatment group were $3.65 \pm 1.37$. It could be concluded that chronic stress affectted the increase in antral follicle's granulosa cell apoptosis in Rattus norvegicus.
\end{abstract}

Keywords : Chronic stress, CUMS, granulosa cell apoptosis, antral follicle 


\section{PENDAHULUAN}

Pergeseran pola pekerjaan dan aktivitas penduduk di era globalisasi saat ini menyebabkan satu individu tidak lepas dari aktivitas dan tuntutan pekerjaan dalam kehidupan sehari-hari sehingga rentan mengalami stres. Prevalensi kejadian stres cukup tinggi yaitu hampir lebih dari 350 juta penduduk dunia mengalami stres dan merupakan penyakit dengan peringkat ke-4 di dunia menurut World Health Organization (WHO) (Waningsiha, 2012). Stres adalah respons tubuh yang sifatnya non spesifik terhadap tuntutan beban yang merupakan respons fisiologis, psikologis dan perilaku dari manusia yang mencoba untuk beradaptasi dan mengatur baik tekanan internal dan eksternal (stresor). Stresor dapat memengaruhi semua bagian dari kehidupan seseorang, menyebabkan stres mental, perubahan perilaku, masalahmasalah dalam interaksi dengan orang lain dan keluhan-keluhan fisik lain yang salah satunya adalah gangguan dalam sistem reproduksi yaitu proses folikulogenesis.

Folikulogenesis merupakan bentuk komunikasi kompleks endokrin antara sistem saraf pusat, hipotalamus dan ovarium. Stres dapat menyebabkan gangguan folikulogenesis. Gangguan ini disebabkan karena adanya gangguan hipotalamus - hipofisis dan ovariun sehingga terjadi gangguan proses folikulogenesis. Stres menginduksi aktivasi dari hipotalamus-hipofisis- adrenal (HPA) axis. Hipotalamus akan mensekresikan corticotrophin releasing hormone ( $\mathrm{CRH})$ yang memacu hipofisis anterior untuk memproduksi adenocorticotrophin hormone (ACTH). Adenocorticotrophin hormone melalui aliran darah, mencapai kelenjar adrenal kemudian membuat kelenjar adrenal mensekresikan suatu hormon sebagai respons adaptif tubuh terhadap stres yaitu glukokortikoid (kortisol pada manusia, kortikosteron pada hewan pengerat).

Glukokortikoid tidak hanya terlibat dalam respon stres tetapi juga merupakan mediator penting untuk peristiwa lain seperti apoptosis (Sasson et al, 2001). Jumlah berlebih dari kortisol dapat mengganggu perkembangan dan pertumbuhan folikel yakni dengan mengganggu fungsi sel granulosa (Hendarto, 2015). Peningkatan tersebut akan memicu terjadinya stres oksidatif dan menginduksi apoptosis sel granulosa. Adanya apoptosis sel granulosa dapat menyebabkan gangguan pada folikulogenesis dengan menurunkan komunikasi antara sel granulosaoosit yang kemudian mempengaruhi suplai nutrisi dan faktor pematangan oosit sehingga mempengaruhi kualitas oosit (Prasad et al, 2016).

Penelitian ini bertujuan untuk membuktikan stres kronis melalui metode Chronic Unpredictabel Mild Stress (CUMS) dapat meningkatkan 
apoptosis sel granulosa folikel antral Rattus norvegicus.

\section{MATERI DAN METODE}

Penelitian ini merupakan penelitian true experiment dengan rancangan menggunakan pendekatan post test only control group design. Penelitian menggunakan 16 tikus Wistar betina yang diberi paparan stres kronis. Hewan percobaan dibagi menjadi dua kelompok, yaitu satu kelompok kontrol tanpa perlakuan dan satu kelompok perlakuan. Kelompok perlakuan akan diberi paparan stres kronis dengan metode Chronic Unpredictable Mild Stress (CUMS) dengan outcome yang diharapkan adalah adanya peningkatan apoptosis sel granulosa.

\section{Persiapan Hewan Coba}

Dilakukan adaptasi dan aklimatisasi terlebih dahulu kepada seluruh hewan coba selama tujuh hari. Penempatan tikus di kandang di dalam ruang penelitian yang sunyi dan tenang juga berventilasi pada suhu kamar $25^{\circ} \mathrm{C}$ dengan kelembaban normal dan serutan kayu dibersihkan dua hari sekali. Makan dan minum tikus dicatat setiap hari.
Pencahayaan disesuaikan dengan cahaya luar pada pagi hari dan malam hari tanpa cahaya lampu. Tikus dijaga dari suasana yang membuat stres.

\section{Sinkronisasi Birahi}

Sinkronisasi birahi dilakukan pada hari ke sepuluh dengan melakukan penyuntikan PGF2 $\alpha$ (Lutaprost $^{\circledR}$ 250, Agrivet, USA) dengan dosis $2 \times 25 \mu \mathrm{g} / \mathrm{g}$ BB secara intraperitoneal. Tujuan dari sinkronisasi birahi yakni untuk penyamarataan siklus birahi hewan coba dan agar mendapatkan fase proestrus pada saat dilakukan pembedahan.

\section{Perlakuan CUMS}

Tikus dibagi menjadi dua kelompok secara acak, yaitu kelompok kontrol dan kelompok perlakuan. Penandaan tikus dilakukan dengan membedakan kandangnya dan mewarnai rambut tikus dengan pewarna carmin sesuai lokasi penomoran. Perlakuan yang diberikan adalah stressor ringan dengan pemberian secara random dan diberikan selama 21 hari.

\begin{tabular}{ccl}
$\begin{array}{c}\text { Hari } \\
\text { ke- }\end{array}$ & $\begin{array}{c}\text { Hari } \\
\text { perlakuan }\end{array}$ & \multicolumn{1}{c}{$\begin{array}{c}\text { Stresor } \\
\text { (lama perlakuan) }\end{array}$} \\
\hline $\mathbf{8}$ & & Sinkronisasi birahi menggunakan pgf2 $\alpha$ : suntikan pertama \\
\hline $\mathbf{9}$ & & \\
\hline $\mathbf{1 0}$ & & Suntikan pgf2 $\alpha$ kedua \\
\hline $\mathbf{1 1}$ & 1 & Dipadatkan dalam satu kandang berisi 5 ekor tikus $(24$ jam $)$ \\
\hline $\mathbf{1 2}$ & 2 & Isolasi di ruang sempit dan gelap $(24$ jam $)$ \\
\hline $\mathbf{1 3}$ & 3 & Diikat ekornya dengan benang $(1$ jam $)$ \\
\hline $\mathbf{1 4}$ & 4 & Kandang dimiringkan $45^{\circ}(5$ jam $)$ \\
\hline $\mathbf{1 5}$ & 5 & Immobilisasi $(2$ jam $)$ \\
\hline
\end{tabular}

Tabel 1 Daftar Perlakuan CUMS 


\begin{tabular}{|c|c|c|}
\hline 16 & 6 & Berenang di air dingin (3 menit) \\
\hline 17 & 7 & Tanpa stresor \\
\hline 18 & 8 & Dipadatkan dalam satu kandang berisi 5 ekor tikus ( 24 jam) \\
\hline 19 & 9 & $\begin{array}{l}\text { Paparan sinar terang } 300-400 \text { lux ( } 4 \text { watt) dilakukan } 2 x \\
\text { sehari ( } 45 \text { menit) }\end{array}$ \\
\hline 20 & 10 & Paparan suara bising dan keras $(80 \mathrm{~dB}),(3 \mathrm{jam})$ \\
\hline 21 & 11 & Tanpa stresor \\
\hline 22 & 12 & Immobilisasi (2 jam) \\
\hline 23 & 13 & Diikat ekornya dengan benang (1 jam) \\
\hline 24 & 14 & Isolasi di ruang sempit dan gelap (24 jam) \\
\hline 25 & 15 & Ditusuk ekornya dengan jarum sepanjang $\pm 2,5 \mathrm{~cm}(1 \mathrm{jam})$ \\
\hline 26 & 16 & Immobilisasi (2 jam) \\
\hline 27 & 17 & Paparan suara bising dan keras $(80 \mathrm{~dB}),(3$ jam $)$ \\
\hline 28 & 18 & $\begin{array}{l}\text { Paparan sinar terang } 300-400 \text { lux ( } 4 \text { watt) dilakukan } 2 x \\
\text { sehari ( } 45 \text { menit) }\end{array}$ \\
\hline 29 & 19 & Dipadatkan dalam satu kandang berisi 5 ekor tikus ( 24 jam) \\
\hline 30 & 20 & Berenang di air dingin (3 menit) \\
\hline 31 & 21 & Ditusuk ekornya dengan jarum sepanjang $\pm 2,5 \mathrm{~cm}(1 \mathrm{jam})$ \\
\hline 32 & 22 & Terminasi \\
\hline
\end{tabular}

\section{Deteksi apoptosis sel granulosa melalui metode TUNEL}

Pengambilan preparat untuk pemeriksaan PA dengan cara jaringan ovarium kanan dan kiri diambil untuk dibuat preparat kemudian dimasukkan ketempat yang tersedia dengan mencampurkan buffer formalin $10 \%$ sebagai pengawet. Sel apoptosis ditunjukan dengan warna coklat pada inti sel.

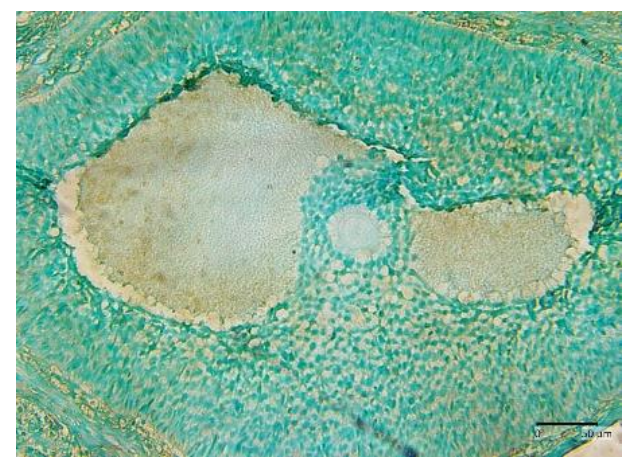

Gambar 1 Folikel antral Rattus norvegicus potongan longitudinal setelah 21 hari perlakuan CUMS pada kelompok kontrol (K1), diamati dengan mikroskop perbesaran 200x.

\section{HASIL DAN DISKUSI}

Hasil pengamatan apoptosis sel granulosa pada kelompok kontrol dan perlakuan dapat dilihat pada gambar 1 dan gambar 2 .

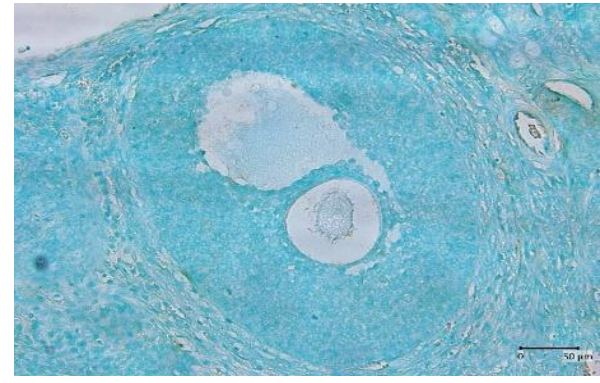


Gambar 2 Folikel antral Rattus norvegicus potongan longitudinal setelah 21 hari perlakuan CUMS pada kelompok perlakuan (P6), diamati dengan mikroskop perbesaran 200x. Sel granulosa yang apoptosis ditunjukkan dengan kemunculan warna kecoklatan yang ditunjukkan dengan panah warna kuning.

Tabel 2 Data Apoptosis Sel Granulosa Folikel Antral

\begin{tabular}{cccc}
\hline Kelompok & N & $\begin{array}{c}\text { Mean } \pm \\
\text { SD }\end{array}$ & $\begin{array}{c}\text { Sig. } \\
(\mathbf{p})\end{array}$ \\
& & $($ ISR) & \\
\hline Kontrol (K) & 8 & $1.12 \pm$ & 0.000 \\
& & 0.48 & \\
Perlakuan & 8 & $3.65 \pm$ & \\
$(\mathbf{P})$ & & 1.37 & \\
\hline
\end{tabular}

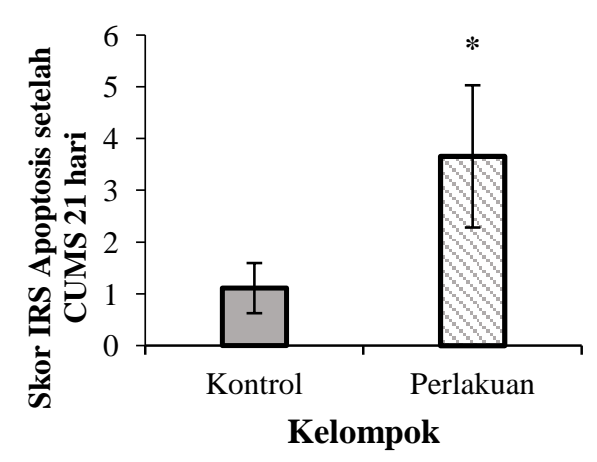

Gambar 3 Apoptosis sel garnulosa folikel antral setelah perlakuan CUMS 21 hari

Berdasarkan tabel 2 dan gambar 3, jumlah rerata apoptosis sel granulosa folikel antral kelompok kontrol (1.12 \pm 0.48$)$ lebih rendah dibandingkan kelompok perlakuan (3.65 \pm 1.37). Distribusi data normal atau tidak pada apoptosis sel granulosa dapat diketahui menggunakan uji Shapiro-Wilk.
Distribusi data dinyatakan normal ( $\mathrm{p}$ $\geq 0.05$ ). Selanjutnya dilakukan analisis menggunakan uji independent t-test untuk melihat hubungan antar kelompok. Hasil uji t-test menyatakan adanya perbedaan bermakna $(\mathrm{p} \leq 0.05)$ apoptosis sel granulosa folikel antral antara kelompok kontrol dan perlakuan dengan nilai $\mathrm{p}=0.000$.

\section{DISKUSI DAN PEMBAHASAN}

Pada penelitian ini, didapatkan perbedaan bermakna apoptosis sel granulosa antara kelompok kontrol dan kelompok perlakuan dengan nilai $\mathrm{p}(0,000)<\alpha$ $(0,05)$.

Terdapat tiga jalur terjadinya apoptosis. Pertama, berkurangnya growth factor, kedua, jalur intrinsik yaitu mempengaruhi fungsi mitokondria melalui aktivasi anggota Bcl2. Kedua, melalui Tumor Necrosis Factor alpha (TNFa) dan Fas Ligan (FasL)-Fas dan reseptor kematian lainnya. Apoptosis juga dapat dimulai oleh sejumlah faktor ekstrinsik yang dapat merusak sel seperti kerusakan DNA dan stres oksidatif yang mengaktifkan jalur sinyal khusus p53 untuk memicu mekanisme apoptosis (Regan et al, 2018).

Sel granulosa adalah sel penting dalam peristiwa folikulogenesis. Sel granulosa selalu berhubungan erat dengan aktivitas steroidogenesis, regulasi growth factor, ploriferasi dan diferensiasi sel (Havelock et al, 2004). Fungsi utama sel granulosa yaitu mendukung 
steroidogenesis di ovarium dan menghasilkan berbagai growth factor dimana growth factor ini akan membantu komunikasi antara sel granulosa dan oosit selama perkembangan folikel dan oosit (Eppig, 2018). Apabila terjadi perubahan pada sel granulosa akan menyebabkan terganggunya pertumbuhan folikel dan maturasi oosit.

Stres menjadi salah satu faktor penyebab utama terjadinya stres oksidatif, menginduksi apoptosis, memperburuk kualitas oosit dan mengurangi hasil reproduksi pada mamalia termasuk manusia (Prasad et al, 2016). Stres dapat menyebabkan tingginya akumulasi Reactive Oxygen Species (ROS) pada ovarium. Tingginya ROS menyebabkan terjadinya stres oksidatif. Hal ini dapat memicu apoptosis sel granulosa maupun oosit sehingga dapat mempengaruhi kualitas oosit (Lissak et al, 2004). Apoptosis dapat menghalangi interaksi sel oosit dan sel granulosa dan mempengaruhi pasokan nutrisi dan faktor pematangan yang dapat mempengaruhi kualitas oosit (Prasad et al, 2016).

Di sisi lain, stres mengakibatkan terjadinya peningkatan glukokortikoid. Glukokortikoid adalah mediator respon stres. Glukokortikoid mempengaruhi banyak kejadian seluler seperti modulasi apoptosis, metabolisme lipid dan karbohidrat, serta aktivitas mitokondria (Da Costa et al, 2017). Tingginya glukokortikoid dapat menyebabkan apoptosis dengan merusak membran mitokondria. Apoptosis ini diatur oleh anggota pro dan anti-apoptosis keluarga Bcl-2. Dalam anggota proapoptosis terdapat protein seperti Bid, Bad, PUMA, Noxa yang mengirimkan rangsangan apoptosis dengan mengaktifkan Bax dan Bak. Bax dan Bak akan membentuk poripori di membran luar mitokondria, kemudian sitokrom $\mathrm{C}$ dilepaskan dari intermembran mitokondria dan berpartisipasi membentuk apoptosome dengan Apaf1 dan caspase 9 kemudian mengaktivasi caspase 3 sebagai eksekutor apoptosis (Prenek et al, 2016).

Selain itu tingginya kadar kortikosteron mengakibatkan ekspresi BMP-15 yang mempunyai salah satu fungsi yaitu meningkatkan ekspresi protein anti-apoptosis Bcl-2 dan menekan protein pro-apoptosis Bax tersebut menurun sehingga menyebabkan apoptosis semakin meningkat.

\section{SIMPULAN DAN SARAN}

Berdasarkan hasil penelitian dan pengolahan data statistik maka disimpulkan bahwa jumlah apoptosis sel granulosa pada tikus (Rattus norvegicus) betina yang mengalami stres kronis melalui metode Chronic Unpredictable Mild Stress (CUMS) lebih tinggi secara signifikan.

Diperlukan penelitian lebih lanjut tentang biomarker lain terjadinya apoptosis pada sel granulosa karena paparan Chronic Unpredictable Mild Stress (CUMS). 


\section{Ucapan Terima Kasih}

1. Dr. Margarita M. Maramis, dr., Sp.KJ (K), selaku pembimbing utama dalam penelitian ini.

2. Jimmy Yanuar Annas, dr., Sp.OG (K), selaku pembimbing dalam penelitian ini.

3. Ketua penguji Dr. Reny I'tishom, M.Si dan anggota penguji Dr. Purwo Sri Rejeki, dr., M.Kes, Dr. Sulistiawati, dr., M.Kes atas kesediaannya menguji dan membimbing dalam perbaikan tesis ini.

4. Dr. Hermanto Tri Joewono, dr., Sp.OG (K) selaku Ketua Program Studi Ilmu Kesehatan Reproduksi Jenjang Magister.

5. Kedua orang tua tercinta, ibunda Rosalina Elza, ayahanda Abdul Hadi, mas Arsya, mbak Amalia, Alda dan Ashilaa dan Apprilian Kurniawan.

6. Alifia Candra Puriastuti, selaku partner dalam penelitian ini.

7. Teman-teman Program Studi Ilmu Kesehatan Reproduksi angkatan 2015 genap dan 2016 ganjil yang tidak dapat saya sebutkan satu persatu.

\section{DAFTAR PUSTAKA}

Dwiningsih, Sri Ratna. 2017. Pengaruh Transplantasi Sel Punca Mesenkimal Sumsum Tulang Belakang Terhadap Ekspresi Reseptor 1 TNF- $\alpha$, mRNA Bcl-2, mRNA p21, mRNA survivin, mRNA VEGF, Apoptosis Sel Granulosa dan Perbaikan Folikulogenesis Pada Mencit Model
Endometriosis
[Disertasi].
Surabaya.
Program
Pascasarjana
Universitas
Airlangga

Fritz, Marc A and Leon Speroff. 2011. Clinical Gynecologic Endocrinology and Infertility $8^{\text {th }}$ Edition. Philadelphia : Lippincott Williams \& Wilkins

Guyton, Ermita I. Ibrahim Ilyas editorial. 2016. Guyton dan Hall : Buku Ajar Fisiologi Kedokteran Edisi Revisi Berwarna Ke-12. Singapura : Elsevier Singapore

Joseph D and Shannon W. 2017. Stress and the HPA Axis: Balancing Homeostasis and Fertility. Int. J. Mol. Sci. 18: 115

López-López, Ana Laura, Herlinda Bonilla Jaime, María del Carmen Escobar Villanueva, Mailinalli Brianza Padilla, Gonzalo Vázquez Palacios, dan Fransisco Javier Alarcón Aguilar. 2016. Chronic Unpredictable Mild stress Generates Oxidative Stress and Systemic Inflammation in Rats. Physiology \& Behavior. 161 : 15-23

Matsuda F, Naoko I, Noboru M and Satoshi O. 2012. Follicular Growth and Atresia in Mammalian Ovaries: Regulation by Survival and Death of Granulosa Cells. Journal of Reproduction and Development. 58(1): 44-50

Maramis, Margarita Maria. 2015. Mekanisme Gangguan Fungsi Memori Kerja Spasial dan 
Fleksibilitas Kognitif Melalui HSP70, IL-6,5-HT,BDNF dan pCREB Pada Model Tikus Putih (Rattus norvegicus) Depresi [Disertasi]. Surabaya. Program Pascasarjana Universitas Airlangga.

Martinez, Jennifer. 2017. Prix Fixe : Efforocytosis as a Four-Couse Meal. In Shigekazu Nagata dan Hiroyasu Nakano ed. Current Topics in Microbiology and Immunology Apoptotic and Nonapoptotic Cell Death. Switzerland : Springer, pp. 126

Parasti, R V. 2017. Pengaruh Transplantasi Sel Punca Mesenkimal Sumsum Tulang Terhadap Ekspresi BMP 15, Apoptosis Sel Granulosa dan Jumlah Folikel pada Mencit Model Endometriosis [Karya Ilmiah Akhir]. Surabaya. Departemen/SMF Obstetri dan Ginekologi Fakultas Kedokteran Univesitas Airlangga

Prasad S, Meenakshi T, Ashutosh N Pandeyi, Tulsidas G, Shail K. 2016. Impact of Stress on Oocyte Quality and Reproductive Outcome. Journal of Biomedical Science. 23:36

Regan S, Phil G, John L, Yee L, Frank A, Arun D. 2018. Granulosa Cell Apoptosis in the Ovarian Follicle. Front. Endocrinol. 9: 61

Scarlet D., N.Ille, R. Ertl, B.G. Alves, G.D.A. Gastal, S.O. Paiva, M.O. Gastal, E.L. Gastal, dan C. Aurich. 2017.
Glucocorticoid Metabolism in Equine Follicles and Oocytes. Domestic Animal Endocrinology. 59: 11 - 12

Setiyono, Awik, Hendy Hendarto, Budi Prasetyo, Margarita M. Maramis. 2015. Pengaruh Tingkat Stres dan Kadar Kortisol dengan Jumlah Folikel Dominan pada Penderita Infertilitas yag Menjalani Fertilisasi Invitro. Majalah Obstetri \& Ginekologi. 23(3): $128-131$

Tiwari M, Chaube Sk. 2016. Moderate Increase of Reactive Oxygen Species Triggers Meiotic Resumption in Rat Follicular Oocytes. J Obstet Gynaecol Res. 42(5): 536-546

Whirledge S and John A. 2010. Glucocorticoids, Stress and Fertility. Minerva Endocrinol. 35(2): 109-125

Whirledge S and John A. 2017. Glucocorticoids and Reproduction: Traffic Control on the Road to Reproduction. Trends in Endocrinology \& Metabolism. Elsevier

Widodo, Agung Dwi Wahyu. 2017. Cell Death : an Overview. One Day Seminar A Cellular and Molecular Approch Cell Death. Surabaya : Universitas Airlangga 